\author{
Olena Buzduhan, \\ PhD (Candidate of Pedagogical Sciences), associate professor, \\ Department of Family and Special Pedagogy and Psychology, \\ South Ukrainian National Pedagogical University named after K. D. Ushynsky, \\ 26, Staroportofrankivska Str., Odessa, Ukraine
}

\title{
INTERACTION OF PRESCHOOL EDUCATIONAL INSTITUTION AND FAMILY IN MORAL EDUCATION OF SENIOR PRESCHOOL CHILDREN
}

The article is dedicated to the research of features of interaction of a preschool educational institution and a family in moral education of senior preschool children; to determination of priority forms and methods of training and education in the work of specialists of preschool education. The article reveals the essence of the interaction between a preschool educational institution and a family. The tasks of interaction of preschool educational institutions and families in moral education of senior preschoolers have been defined and realized. According to defined tasks, the system of measures for their implementation has been developed. Unified approaches in the organization of moral education of children through the involvement of the latter into moral values in different types of activity have been defined.

Keywords: moral education, interaction, preschool educational institution, family, senior preschool children.

\section{Introduction}

Over the last decades, the interest of pedagogical science in the issues of formation of an individual's moral sphere has increased. Moral education of a personality under modern conditions of our society development is a problem which concerns scientists of various branches of sciences, therefore it is a subject of many psychological and pedagogical researches. It is significant for democratization of the Ukrainian society, as the way to success in modern Ukrainian education is only through moral revival, and therefore the practical task of a preschool teacher is to improve the environment in which the children live. As K. Ushynskyi noted, "Only a person can influence the development and formation of another person, only a character can form a character ... The reasons of such moral magnetism are hidden deeply in human nature" [10, p.123].

To ensure the favorable living and educational conditions of a child, the formation of the bases of a fullfledged and harmonious personality, it is necessary to strengthen and develop the close connection and interaction of preschool educational institutions with families.

The law "On Education" states that "Parents are the first teachers. They are obliged to lay the foundations for the physical, moral and intellectual development of the child's personality at early age" [5].

According to it, the position of preschool educational institution in work with families also changes. Each preschool educational institution not only brings up a child, but also advises parents on the issues of children' general education and moral education in particular. A preschool teacher is not only the teacher of children, but also a partner of parents in children's education.

The issue of moral education in various aspects was studied extensively by T. Aleksieienko, O. Arnautova, O. Barabash, I. Bekh, O. Vyshnevskyi, I. Hrebennikov, O. Dokukina, O. Kononko, O. Kosarieva, V. Kotylo, S. Ladyvir, T. Markova, T. Naumenko, V. Pavlenchyk,
V. Postovyi, T. Ponimanska, M. Stelmakhovych, V. Sukhomlynskyi. It is reasonable to distinguish views of A. Adler, T. Hordon, R. Dreikurs, Ya. Hamialiaynen and other scientists among foreign researchers. The interaction of a family and educational institution within the system of pedagogical education of parents was developed by S. Zaytseva, V. Postovyi, O. Khromova and others. The problem of family education was studied by Yu. Azarov, T. Aleksieienko, I. Bekh, M. Yevtukh, A. Makarenko, M. Stelmakhovych, V. Sukhomlynskyi.

The aim of the article is to define the tasks of interaction between preschool educational institutions and families in moral education of senior preschoolers and offer the system of measures for their implementation.

\section{Discussion}

According to the law "On Education" and the Model regulations on pre-school education, one of the main tasks kindergartens face is "interaction with the family to ensure the full development of a child". Therefore, searching the effective forms, methods and means of moral education of younger generation, senior preschool children in particular, cooperation of a preschool educational institution and a family is important.

The essence of the interaction between preschool educational institutions and families is coordination of their requirements, actions for the benefit of a child, active involvement of parents in pedagogical process. The task of interaction is providing the optimum conditions to a child for his/her full physical and mental development in a family and kindergarten, assistance in satisfying his/her needs for emotional and personal communication, development of his/her creative interests and abilities, increasing the level of formation of pedagogical and moral culture of preschool teachers and parents. For better and more responsible approach to upbringing of a child, parents together with preschool teachers should build their relationships on the principles of mutual respect, under- 
standing of the importance of each other and realization that such a partnership will have a lasting influence in favor of all. Preschool teachers and parents act in the interests of a child, make decisions about his/her upbringing and education and create appropriate conditions for him/her.

The success of formation of the personality as a whole depends on the extent of coordination of these relationships. In particular, interaction in the pedagogical process of a family and preschool educational institution is able to form an individuality, activate personal creative potential, moral values not only of a child, but also of pedagogues and parents. Interaction based on the principles of cooperative interpretation involves mutual assistance, cooperation, coordination of efforts, and is considered as the complete phenomenon in psychological and pedagogical system.

To improve work with parents is to make changes that enrich the content and forms of work, improve its various characteristics, make it more appropriate, modern, and flexible if it is necessary.

The process of improvement is long and continuous. It can be carried out in various directions. Methodological basis of universal education involves popular pedagogical experience and achievements of domestic and foreign scientific pedagogy on the issues of family education.

To be sufficiently effective, pedagogical universal education must be differentiated. It should provide qualitative distinctions and features of various groups of families which are related to them.

N. Krupska wrote in her "Pedagogical Works": "Working with parents is a big and important issue. Here we must provide the sufficient level of parents' knowledge helping them in the matter of self-education, equipping them with a known pedagogical minimum, engaging them in the work of kindergartens".

N. Krupska repeatedly emphasized that the important aspect of the interaction of a preschool educational institution and a family is that the preschool educational institution serves as an "organizing center" and "influences home education", so it is necessary to organize the interaction of the kindergarten and the family as much as possible in upbringing children. "... A huge force is in their commonwealth, in mutual care and responsibility". At the same time, she believed that it is necessary to help those parents who do not know how to educate children [6].

In a modern family the special role belongs to functions of spiritual communication, emotional support, moral education, since society, educational institutions cannot provide such unique conditions for emotional and spiritual life of the personality which are owned by a family. Exactly through living in a family, its purposeful efforts, the person learns, comprehends the human essence, responsibilities to other people, first of all to parents and children, approves all human in him-/herself. For this purpose he/she needs to grow up in a family in which the spirit of love dominates; everybody treats each other sensitively and carefully. Lessons of kindness, love, abil- ity for empathy cannot be gathered from books. These qualities are developed in a child first of all during his/her interaction with people closest to him. Feeling love for him-/herself, watching how it is manifested, the child learns to love other people. And love for the child grows out from mutual love of parents, from the lessons of love received by them in their childhood, from sincerity of their relations with their parents [4].

The scientific problem of moral education is based on the concept of "morals", "morality". In order to determine the main content of the process of moral education, it is necessary to turn to the domestic tradition of interpreting this concept. According to O. Pavlovska, morals is a set of values that orient people in practical relations. These are ideals, norms, principles, views on good and evil, on the meaning of life, dignity, honor, on the whole system of personal and social relations [7, p. 44].

According to I. Bekh, morality is "a form of social consciousness concerning two spheres - the world of people and the world of things, which can act both as a subject-subject, and as a subject-object relation" [1, p. 8]. Therefore, in our definition, morality bears in itself moral values and ideals reflecting the level of development of an individual and people in general. Being the core of the personality, morality defines the nature of the person's life aims and the results of his/her activity.

I. Pestalotstsi divides elementary education into intellectual, physical and moral. In his opinion, all these three aspects of education must be realized in indissoluble unity, starting from the first day of a person's life. Proceeding from the fact that "a child's birth time is the first hour of his/her education" [8, p. 80], I. Pestalotstsi put forward the requirement - to diversify and develop harmoniously all the natural forces and abilities of a child. Concerning moral education, he believes that its elements, like the physical and mental ones, are established in a family.

The term "moral education" in pedagogical science is widely used, but, as H. Vashchenko pointed out, there is no "clear definition". So, the scientist explained that educational technology is identified with educational methods, and the introduction of this concept is considered to be "a tribute to fashion" [2, p. 34].

Investigating educational values of young generation in Ukraine, M. Stelmakhovych emphasized that the education system has to bring up the highly moral personality on the basis of national achievements: "Wisdom of our people goes from a grandfather and a great-grandfather, a father and a mother, a family, a home and mother tongue, Mother Earth, from the clear sky and the light sun, Mother Nature, from a kind heart and whole soul, deep human feelings and experiences, crystal honesty and humanity, light spirituality, warm love for children, from the spirit of Mother-Ukraine" [9, p. 131].

V. Belousova considers moral education as a specially organized interpersonal interaction between a teacher and a child based on the norms and principles of humanism. The pedagogue understands humanization of education as the humanizing of relationships that will provide a 
moral and emotional atmosphere of mutual understanding, respect and concern for another person, disinterested attitude to each person not as a means of achieving one's own interests, but as a goal. "In this case," the teacher emphasized, "the other person is perceived as the highest life value, causing the attitude toward him-/herself, which is adequate to perception" [3, p. 187].

Moral education of a personality is aimed at the formation of moral breeding, which involves a system of moral knowledge, skills, beliefs, attitudes, norms. We defined the tasks of moral education as the process of transforming socially significant norms, principles that regulate mutual relations, universal moral values into individual qualities and formation of appropriate moral qualities on this basis.

According to certain tasks, a system of measures for their implementation has been developed, which provided filling them with new contents, if necessary, rearranging the emphasis on the existing forms and methods of the educational process in order to activate the processes of the formation of moral values and, subsequently, the moral sphere of a personality at preschool age. Senior preschool children (96 children), their parents (32 people) and preschool teachers (12 people) were involved in the work on formation of moral values of children of senior preschool age.

We tried to plan the work on formation of moral values of senior preschoolers in the following way: acquaintance with the rules of behavior of children, preschool teachers and parents, the development of educational and pedagogical tasks; creating the necessary conditions for organizing activities for literary and other children's activities; inclusion of preschool children in step-by-step activities; the development of the content of activities, the selection of works for children; the organization of pedagogical and educational work with parents.

With the purpose of enriching the knowledge of parents on the matter of moral education of senior preschool age children, an algorithm of meetings with parents has been developed, which is focused on interaction with them in moral education of senior preschool age children.

Psychological and pedagogical education was carried out in collective and individual forms on the basis of the goals of moral education of senior preschoolers. Collective psychological and pedagogical education of the parents of the group was conducted in the form of conversations with parents, reading conferences on the education of moral values. The program of conversations with parents on moral education of senior preschool age children included the following aspects:

- peculiarities of psychological and physiological development of the children of the group and taking them into account in family moral education;

- the most acute problems of moral education of children of senior preschool age.
The involvement of parents into the actions, which contributed to the joint activities of parents and children, was the following stage of the purposeful work. Parents were involved in holding performances, concerts, various events, family holidays ("Crafts from Natural Material", "Birthday", "Sports Day", "Daddy, Mom and me are a close family"). Preparation and design of the exhibition "Everything should be first-rate in a person, his face, clothes, soul and thoughts" was one of the stages of the work. Due to such holidays and entertainment, both children and parents were became familiar with the sources of folk art, the history of their people, their traditions.

The implementation of the project "Big World of a Little Child" was the key stage. Its implementation involved solving the following tasks:

- to enrich visual and sensual ideas of children about moral qualities, dignity and socially recognized behavior;

- to promote understanding of the importance of observing moral and ethical rules by children;

- to understand, distinguish positive and negative actions, to assess them;

- to expand the children's ideas of such feelings as: sensitivity, kindness, humanity;

- to encourage children to observe moral rules in everyday life depending on a situation;

- to understand the inner state of another person, that is, "deep knowing of a person by the soul";

- to form the ability to express the feelings adequately;

- to explain morally justified ways of counteraction to the evil.

The parents were interested in these recommendations, conversations, advice at the parents' meetings, consultations, and projects. Common approaches to the organization of children's moral education through access to moral values in various activities have been defined.

Conclusions

All of the aforesaid allows us to confirm that in the current state of the Ukrainian society, when a wide range of values is exposed to a revaluation, the moral education of children of senior preschool age becomes of special importance. The realization of the tasks of moral education must take place according to the uniform requirements in the society, family and educational institution. Thus, the work, which has been carried out, has united the teachers, children and their parents in formation of the bases of morality among the children of senior preschool age. Because of close interaction with parents, we have had an opportunity to see the children in different situations, and consequently, to help parents understand the specific features of their child, to form his/her value life guides. The carried out research does not cover all the aspects of moral education of children of senior preschool age. The issues of moral education of senior preschoolers through access to moral values in various activities should be investigated further. 


\section{REFERENCES}

1. Bekh, I. (1992). Psikhologicheskiye osnovy nravstvennogo razvitiya lichnosti [Psychological bases of moral development of a personality]. Extended abstract of doctor's thesis. Kiyv: Pedahohichnyi institut imeni M. P. Dragomanova [in Russian].

2. Vashchenko, H. (1994). Vykhovnyi ideal [Educational ideal]. Poltava: Poltavskyi visnyk [in Ukrainian].

3. Bielienka, H. V., Bielkina, E. V., Bohinich, O. L., Bohdanets-Biloskalenko, N. I., Vasylieva, S. A., Vashulenko, M. S. et al. (2012). Dytyna: Prohrama vykhovannia $i$ navchannia ditei vid dvokh do semy rokiv [A child: The program of education and training of children from two to seven]. $3^{\text {rd }}$ ed., rev. Kyiv: Kyivskyi universytet imeni B. Hrinchenka [in Ukrainian].

4. Dubrova, V. (1997). Teoretiko-metodicheskiye osnovy vzaimodeystviya detskogo sada s semyey [Theoretical and methodological bases of interaction of a kindergarten with a family]. Minsk: Izdatelskaya firma "Vozrozhdeniye" [in Russian].

5. Zakon Ukrainy "Pro osvitu": redaktsiia vid 19.02.2016 №1060-XII [Law of Ukraine "On education" dated February, 19, 2016, No. 1060-XII]. Retrieved from:

\section{ЛІТЕРАТУРА}

1. Бех И. Д. Психологические основы нравственного развития личности : автореф. дис... д-ра психол. наук : 19.00.07 / И. Д. Бех : Киевский пед. институт им. М. П. Драгоманова. - Киев, 1992. - 43 с.

2. Ващенко Г. Виховний ідеал : підручник для педагогів, виховників, молоді і батьків / Г. Ващенко. Полтава : Полтав. вісн., 1994. - 190 с.

3. Дитина : Програма виховання і навчання дітей від двох до семи років / наук. кер. проекту О. В. Огнев'юк, К. І. Волинець ; наук. кер. програмою : О. В. Проскура, Л. П. Кочина, В. У. Кузьменко, Н. В. Кудикіна ; авт. кол. : Г. В. Бєлєнька, Е. В. Бєлкіна, О. Л. Богініч, Н. І. Богданець-Білоскаленко, С. А. Васильєва, М. С. Вашуленко [та ін.] / Мін. осв. і наук., мол. та спорту України, Головн. упр. осв. і наук. викон. орг. Київміськради (КМДА), Київ. ун-т ім. Б. Грінченка. - 3-є вид., доопр. та доп. - К. : Київ. ун-т ім. Б. Грінченка, 2012. -492 с.

4. Дуброва В. П. Теоретико-методические основы взаимодействия детского сада с семьей : Учебное пособие / В. П. Дуброва. - Минск : Издательская фирма “Возрождение”, 1997. - С. 128-141. http://zakon3.rada.gov.ua/laws/show/1060-12/page3 [in Ukrainian].

6. Krupska, N. (1965). Pedahohichni tvory: Doshkilne vykhovannia. Pytannia simeinoho vykhovannia $i$ pobutu [Pedagogical works: Preschool education. Issues of family education and life]. (Vols. 6). Kyiv: Radianska shkola [in Ukrainian].

7. Nechayeva, V. G., Markova, T. A., Zhukovskaya, R. I. et al. (1984). Nravstvennoye vospitaniye $v$ detskom sadu [Moral education in kindergarten]. V. G. Nechayeva, T. A. Markova (Eds.). $3^{\text {rd }}$ ed., rev. Moscow: Prosvescheniye [in Russian].

8. Pestalotstsi, I. (1981). Izbrannyye pedagogicheskie sochineniya: [Selected pedagogical works]. (Vol. 1). Moscow: Pedagogika [in Russian].

9. Stelmakhovych, M. (1996). Ukrainska rodynna pedahohika [Ukrainian family pedagogy]. Kyiv: ISDO [in Ukrainian].

10. Ushinskiy, K. (1974). Chelovek kak predmet vospitaniya: Opyt pedagogicheskoy antropologii [A person as a subject of education: Experience of pedagogical anthropology]. Moscow: Pedagogika [in Russian].

5. Закон України «Про освіту» : редакція від 19.02.2016 № 1060-XII [Електронний ресурс]. - Peжим доступу http://zakon3.rada.gov.ua/laws/show/1060-12/page3.

6. Крупська Н. К. Педагогічні твори : В 10т. Т. 6. Дошкільне виховання. Питання сімейного виховання і побуту / Н. К. Крупська; за ред. М. К. Гончарова, А. І. Каїрова. - К. : Радянська школа, 1965. - 455 с.

7. Нечаева В. Г. Нравственное воспитание в детском саду : Пособие для воспитателей / В. Г. Нечаева, Т. А. Маркова, Р. И. Жуковская и др.; под ред. В. Г. Нечаевой, Т. А. Марковой. - 3-е изд., испр. и доп. - М. : Просвещение, 1984. - 272 с.

8. Песталоцци И. Избранные педагогические сочинения : В 2-х томах / И. Песталоцци. - Т.1. - М. : Педагогика, 1981. - 336 с.

9. Стельмахович М. Г. Українська родинна педагогіка : Навч. посібн. / М. Г. Стельмахович. - К. : ІСДО, 1996. - 288 c.

10. Ушинский К. Д. Человек как предмет воспитания. Опыт педагогической антропологии : избр.пед.соч. : [в 2 т.] / К. Д. Ушинский. - М. : Педагогика, 1974. - $776 \mathrm{c}$.

Олена Анатолї̈вна Буздуган, кандидат педагогічних наук, доцент кафедри сімейної та спеціальної педагогіки і психології, Південноукраїнський начіональний педагогічний університет імені К. Д. Уиинського, вул. Старопортофранківська, 26, м. Одеса, Украӥна

\section{ВЗАСМОДІЯ ДОШКІЛЬНОГО НАВЧАЛЬНОГО ЗАКЛАДУ ТА СІМ'Ї У МОРАЛЬНОМУ ВИХОВАННІ СТАРШИХ ДОШКІЛЬНИКІВ}

Статтю присвячено дослідженню особливостей взаємодії дошкільного навчального закладу та сім'ї у моральному вихованні старших дошкільників; визначенню пріоритетних форм і методів навчання та виховання у роботі 
фахівців дошкільної освіти. В результаті проведеного аналізу було з'ясовано, що моральне виховання є значущим для демократизації українського суспільства. У статті також розкрито сутність взаємодії дошкільного навчального закладу і сім”ї, яка полягає в узгодженні їхніх вимог, дій в інтересах дитини, активному залученні батьків до педагогічного процесу. Визначено завдання взаємодії дошкільного навчального закладу та сім'ї, а саме: забезпечення в сім’ї та дошкільному навчальному закладі оптимальних умов для повноцінного фізичного та психічного розвитку дитини, сприяння задоволенню іiі потреби в емоційно-особистісному спілкуванні, розвиток іiі творчих інтересів i здібностей; підвищення рівня сформованості педагогічної, моральної культури вихователів і батьків. Завданнями морального виховання визначено процес трансформації суспільно значущих норм, принципів, регулюючих взаємовідносини, загальнолюдських моральних цінностей в індивідуальні якості й формування на цій основі відповідних моральних якостей. Згідно з визначеними завданнями, було розроблено систему заходів щодо їх реалізації, яка передбачала наповнення новим змістом, при потребі переставлення акцентів в уже існуючих формах і методах освітнього процесу, з метою активізації процесів формування моральних цінностей, а згодом і моральної сфери особистості в дошкільному віці. Роботу з формування моральних цінностей дітей старшого дошкільного віку побудовано таким чином: знайомство з правилами поведінки дітей, вихователів і батьків, розробка навчальних і виховних завдань; створення необхідних умов для організації діяльності з літературою та іншою дитячою діяльністю; включення дошкільнят у поетапну діяльність; розробка змісту діяльності, підбір художніх творів для дітей; організація педагогічної та освітньої роботи з батьками. Також визначено єдині підходи в організації морального виховання дітей через залучення останніх до моральних цінностей у різних видах діяльності.

Ключові слова: взаємодія, дошкільний навчальний заклад, сім’я, моральне виховання.

Submitted on April, 4, 2017

Reviewed by Doctor of Pedagogy, prof. I. Buzhyna

UDC: $37-047.64+376.3$

DOI: https://doi.org/10.24195/2414-4665-2017-4-25

\author{
Olena Balashova, \\ President of International Charitable Foundation "Inshe Zhyttia", \\ 30/35, Shelkovichna Str., Kyiv, Ukraine
}

\title{
IMPLEMENTATION OF INCLUSION INTO UKRAINIAN EDUCATIONAL SPACE
}

The paper aims to present the results of assessing the modern state of inclusive education implementation, pedagogues' and parents' personal readiness for it. Inclusive education is not considered as a particular type or level of education, it is a new organization of the educational process. Inclusive education can be carried out during the implementation of educational programs at all levels of basic education, it is important that each student is provided with all necessary conditions, all students study together. In order to determine the current state of inclusive education implementation in Ukraine an experimental study was conducted that included surveys of direct participants of the educational process - teachers of secondary schools in Kyiv, Odessa, parents of children with special educational needs (SEN) and parents of "normal" children. The total number of participants in the experiment was 480 people (parents of children with SEN, parents of healthy children, teachers, representatives of educational institutions' administration, psychologists, social workers, leaders of clubs). According to the data obtained, it can be stated that being aware of the inclusive education content, the respondents mention a low level of inclusion in Ukrainian educational institutions. A barrier-free environment can be considered as a prerequisite for inclusive education development. Schools and preschools built in recent years, do not fully meet the requirements of a barrierfree environment, more often the adaptive learning environment is formed. One of the conditions for the success of inclusive education development is tolerant attitude of the society to people with special needs. Development of partnership with students' parents is an essential precondition that requires further consideration and elaboration of various cooperation forms, such as workshops, seminars, round tables, weekend clubs and others. The importance of institution's social and psychological services is extremely important, at the same time, the importance of specialists in this field in the process of inclusion requires qualitative changes, including psychological and pedagogical support of the educational process.

Keywords: inclusion, inclusive education, children with special educational needs, barriers, factors.

\section{Introduction}

Integration of children with special educational needs (SEN) into general educational space of Ukraine as an area of the entire education system humanization is a key priority of the state policy and aims to create conditions for getting education of high quality by children according to their individual abilities and capabilities. Since 2001, Ukraine has intensified legislative activity 